\title{
Technical Note: Mechanical harvesting of plains pricklypear for control and feeding
}

\author{
D.M. MUELLER, M.C. SHOOP, AND W.A. LAYCOCK
}

Mueller is range technician, USDA-ARS Central Plains Experimental Range, County Rd. 37, Nunn, Colo. 80648. Shoop is collaborator, USDA-ARS Rangeland Resources Research, Unit 1701 Center Avenue, Fort Collins, 80523. Laycock is Dep. Head, Range Management, University of Wyoming, Laramie 82071 (formerly range scientist, USDA-ARS, Fort Collins, Colo. 80526).

\begin{abstract}
Plains pricklypear cactus (Opuntia polyacantha $\mathrm{L}$.) is abundant on the Central Great Plains with dry matter yields from 1,500 to $2,000 \mathrm{~kg} / \mathrm{ha}$. Cactus spines prevent cattle from grazing as much as $50 \%$ of the herbage around the plant. Pricklypear pads are quite palatable once spines have been removed. The possibility of simultaneously controlling and feeding plains pricklypear led to development of machinery for harvesting cactus. The harvesting machine is a side-delivery rake modified to uproot and windrow pricklypear which is later despined and fed to cattle. Machine harvesting was compared to hand harvesting on both a sandy loam and a clay loam site. There was no significant difference in cactus removal between hand and machine harvested plots or significant damage to desirable forage species. Pricklypear phytomass removal by the harvester averaged $89 \%$ and $88 \%$ on the sandy and clay loam sites, respectively. This provided an average of $1,166 \mathrm{~kg} / \mathrm{ha}$ cactus as potential feed and increased availability of desirable forage species.
\end{abstract}

Key Words: cactus, machine harvester, range improvement, Opuntia polyacantha, shortgrass range

Over 2,400,000 ha of rangeland in eastern Wyoming and northeastern Colorado have pricklypear (Opuntia polyacantha L.) infestations of economic consequence (Alley and Lee 1969, Sims 1973). Pricklypear dry matter yields frequently exceed 2,000 $\mathrm{kg} /$ ha. Pricklypear spines make about $50 \%$ of perennial grass production in and around the plant unavailable for grazing (Smith et al. 1985). Several methods for eradicating it have been attempted. Picloram (4-amino-3,5,6,-trichloro-2-pyridinecarboxylic acid) and Silvex [(2-(2,4,5-trichlorophenoxy) propionic acid] provide effective chemical control (Thatcher et al. 1964, Hyde et al. 1965, Sims 1973). Silvex is no longer available for use and picloram may damage desirable forage species and leave cactus pads intact for 2 or more years. Other control methods have included blading, beating, and burning (Hyde et al. 1965). Blading causes damage to other vegetation. Beating leaves cactus pads on the ground where they can start new plants by rooting (Costello 1941, Hyde et al. 1965, Laycock 1982). Burning cactus can result in nearly $100 \%$ control if sufficient forage ( $500 \mathrm{~kg}$ / ha continuous grass) is available as fuel (Smith et al. 1985).

Cattlemen historically have used pricklypear both as a drought feed and as forage (Griffiths 1906, Woodward et al. 1915). In some instances it is still used as emergency feed during drought. Chemical analysis and digestion trials have shown plains pricklypear digestibility to be equal or superior to that of high quality hay

Manuscript accepted 25 Sep. 1993.
(Shoop et al. 1977). Attempts have been made to make pricklypear more available as a feed by removing spines in the field with fire. Shoop (personal communication) found that $670 \mathrm{~kg} /$ ha of herbage is required for fuel to effectively singe cactus spines in place. Some protected spines are impossible to remove even with greater amounts of fuel. To singe or destroy pricklypear in place, the current year's forage that must be burned is lost as livestock feed.

The possibility of simultaneously controlling and collecting plains pricklypear for later feeding to livestock led to development of cactus harvesting machinery at the Central Plains Experimental Range (CPER) in northeastern Colorado. We postulated that a harvester would pay for the cost of pricklypear control by making the cactus available as feed.

The objective of this study was to modify existing machinery to uproot and windrow cactus with minimal turf or soil disturbance and to develop equipment to pick up pricklypear for spine removal and feeding.

\section{Equipment}

A front-mounted International Harvester No. 8, high-speed parallel-bar type, side-delivery rake ${ }^{1}$ was modified for uprooting and windrowing pricklypear. Major modifications included the addition of vertically adjustable wheels, replacement of the solid mount to the tractor with a rotating mount (Fig. 1), and altering the teeth to a fork like configuration by attaching a small 3pronged fork at a $45^{\circ}$ angle to the tip of each rubber-mounted rake tooth (Fig. 2). Wheels, located at the rake axis, gave instant response to any change in ground contour and allowed reel height to be adjusted. The rotating mount used a modified truck front axle which attached the rake to the tractor and provided a bearing surface on which the rake frame could rotate in response to any irregularities in terrain encountered by the rake wheels. The $45^{\circ}$ angle on the fork allowed it to slide under the cactus pads. Spacing the fork teeth $2.5 \mathrm{~cm}$ apart prevented cactus pads from escaping between the teeth, enabling the rake to pull cactus from the ground.

The rake used 4 bars with 30 teeth on each bar to accomplish raking action. The rake was powered at a reel speed of $165 \mathrm{rev} / \mathrm{min}$ by a hydraulic motor that delivered $9.7 \mathrm{kw}$ when driven by the tractor hydraulic system which pumped 38 liters/min at $16 \mathrm{mPa}$.

Thirteen-millimeter-hardware cloth around the front and top of the rake prevented cactus pads from being tossed in the air, while $2.5-\times 15-\mathrm{cm}$ chains at the bottom of the screen prevented pads from escaping underneath (Fig. 1). Cactus pads torn loose by the

IMention of a trademark or manufacturer by the USDA does not imply its approval to the exclusion of other products or manufacturers. 


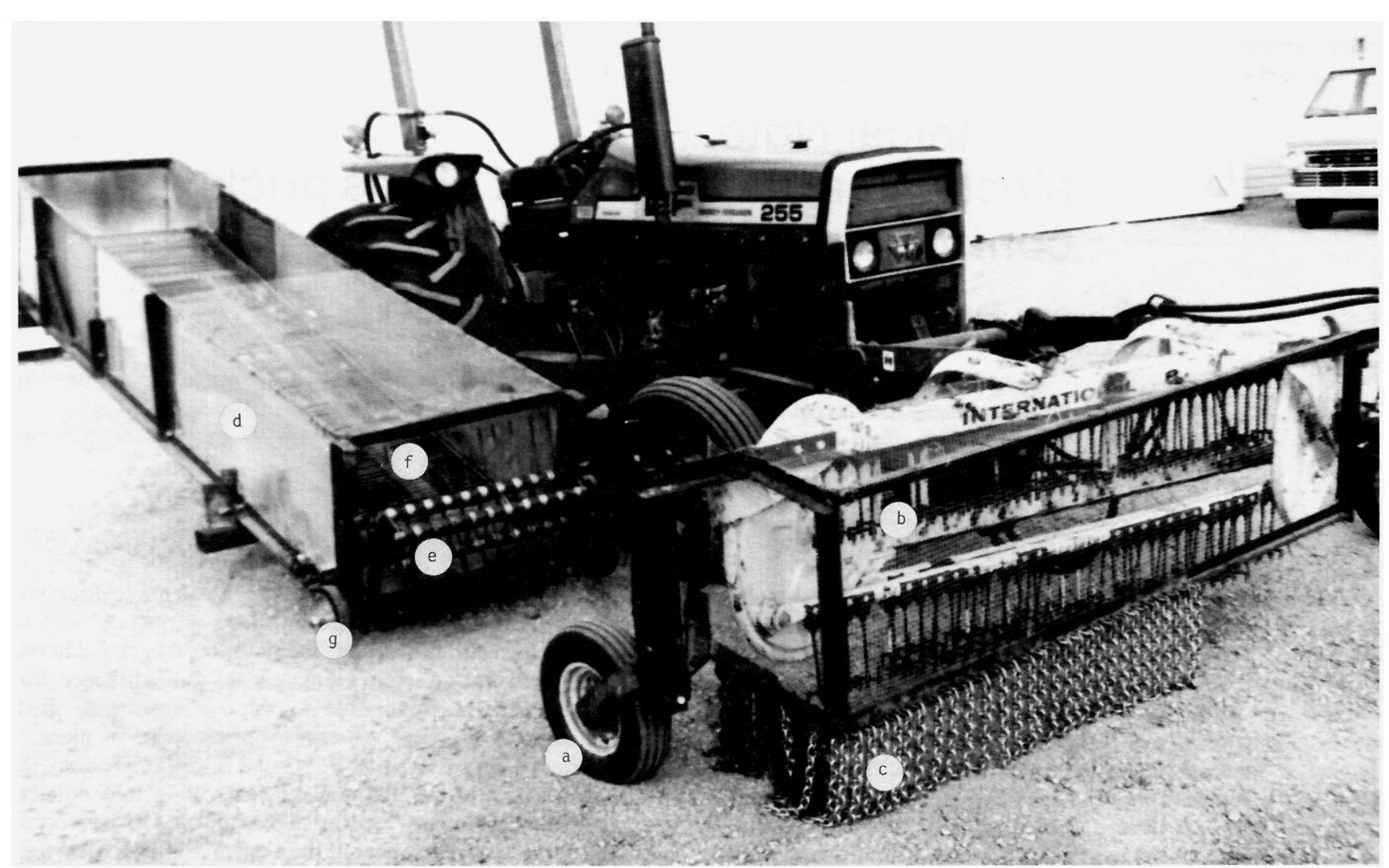

Fig. 1. Mechanical pricklypear harvester developed by USDA-ARS at Central Plains Experiment Station. Letters refer to the following: (a) 30-cm diameter wheels; (b) 1.3-cm screen; (c) 1.3-m chain; (d) conveyor; (e) pickup; (f) 2.5- $\times 1$ - $\times$ 73.7-cm apron chain; (g) 20 -cm wheels.

\section{MODIFIED}

RAKE TOOTH

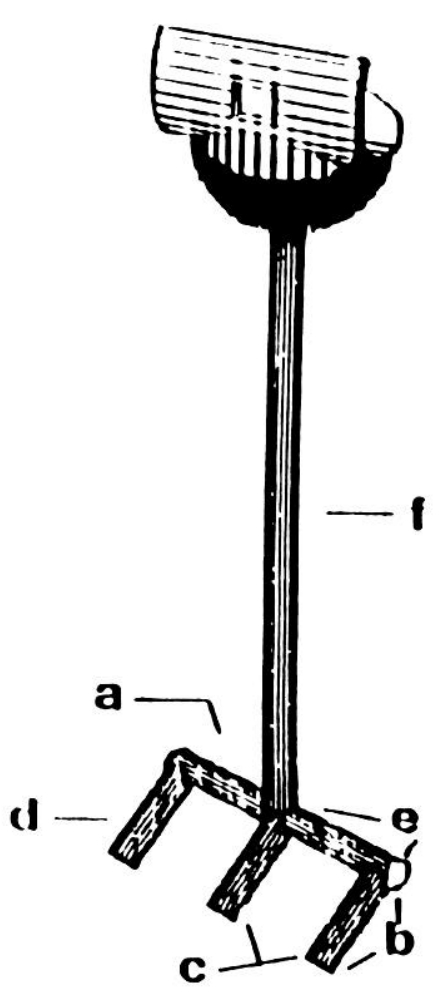

\section{ORIGINAL \\ RAKE TOOTH}

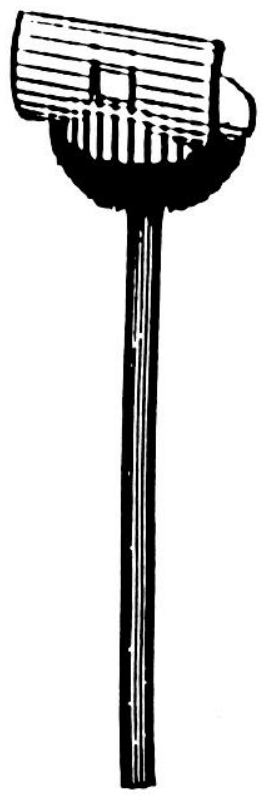

Fig. 2. Modified rubber-mounted rake tooth. Letters refer to the following:

(a) $7.5-\mathrm{cm}$ long fork; (b) $45^{\circ}$ angle; (c) 2.5 -cm spacing between fork teeth; (d) 2.5-cm tooth; (e) $28^{\circ}$ angle; (f) $20-\mathrm{cm}$ rubber-mounted rake tooth.

rake were windrowed.

A pickup device lifted cactus pads from the windrow onto the conveyor (Fig. 1). The pickup, mounted in front of the conveyor wheels, consisted of 6 pieces of pipe attached to an apron-drivegear assembly (Fig. 3). Ten, spring steel teeth were mounted $5.0 \mathrm{~cm}$ apart on each pipe (Fig. 3). The pickup reel was rotated in the direction of travel at approximately $166 \mathrm{rev} / \mathrm{min}$ by the same hydraulic motor that powered the apron chain.

One end of a $0.3-\times 74-\times 30-\mathrm{cm}$ sheet metal scoop was mounted to the pickup drive shaft while the other end rested on the apron. As the scoop scraped along the ground it prevented cactus pads from escaping under the conveyor. Slots were cut into the scoop so that unwanted residue could escape (Fig. 3). An onion conveyor chain was selected because it appeared to be the correct size to retain cactus pads yet allow trash to fall through the chain (Fig. 1). Adjustable wheels at the front of the conveyor ensured a constant height above the ground (Fig. 1).

A separate hydraulic system powered the conveyor and pickup attachment. A PTO-drive 12-kw rated hydraulic pump delivered 68 liters $/ \mathrm{min}$ at $10 \mathrm{mPa}$ when operated at $540 \mathrm{rev} / \mathrm{min}$. A $7 \mathrm{kw}$ motor drove the apron chain at $31 \mathrm{~cm} / \mathrm{s}$.

\section{Methods}

The study to test the pricklypear harvester was conducted at the Central Plains Experimental Range near Nunn in northeastern Colorado on both a sandy loam and a clay loam site. Perennial grasses dominated the experimental areas on both soils. In 1980 blue grama [Bouteloua gracilis (H.B.K.) Lag. ex Griffiths] made up $63 \%$ of nonpricklypear phytomass on the sandy loam site, while buffalo grass [ Buchloe dactyloides (Nutt.) Englm.] made up 57\% of composition of the clay loam site. Common shrubs were spreading wild buckwheat (Eriogonum effusum Nutt.) on the 

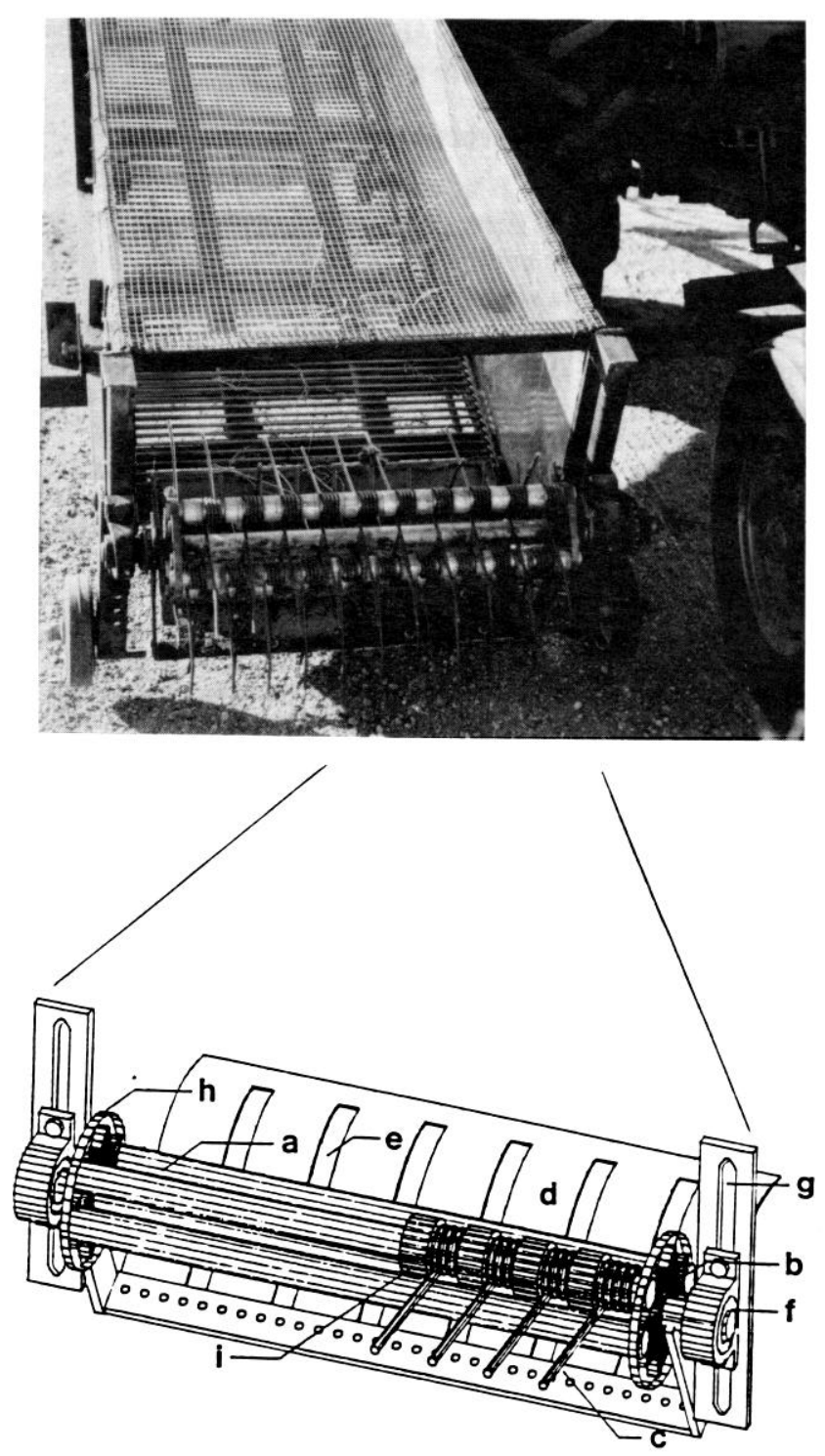

Fig. 3. Pickup. Letters refer to the following: (a) $3.2-\times 69-\mathrm{cm}$ pipe; (b) apron drive assembly for $5-\times 1-\times 74-\mathrm{cm}$ apron chain; (c) $0.6-\times 20-\mathrm{cm}$ spring steel teeth; (d) $0.3-\times 74-\times 30-\mathrm{cm}$ curved sheet metal scoop; (e) 2.5-cm slots; (f) 3-cm HD pillow block bearing; (g) $1.3-\mathrm{cm}$ slots; (h) 13-cm hose clamps; (i) 5-cm spacers.

sandy loam site and fringed sagewort (Artemisia frigida Willd.) on the clay loam site. The most abundant forb on both sites was scarlet globemallow [ Sphaeralcea coccinea (Pursh) Rydb.]. Plains pricklypear accounted for approximately $7 \%$ of the vegetative cover and $58 \%$ of the total aboveground standing crop on both sites.

Machine-harvest and hand-harvest treatments were tested against a control (no treatment) on both sandy loam and clay loam sites in May 1980 and April 1981. Machine harvesting was performed without a pickup and conveyor in 1980 . Windrows formed by the machine harvester in 1980 were removed by hand. In 1981 the harvester used a pickup and conveyor to remove windrows as they were formed. Hand-harvesting and removal was done in both 1980 and 1981 with hand held forks and rakes. Both treatments (handharvest and machine-harvest) removed cactus either by uprooting or breakage of the pads at ground level. The harvester was tested in both a sandy loam and clay loam soil, to determine if soil type influenced harvester efficiency. Completely randomized, long, narrow plots $(9.1-\times 54.9-\mathrm{m})$ were used to facilitate efficient operation of the tractor harvester. Each plot was subdivided into 2
Table 1. Grass, forb, shrub, and cactus August 1980 and 1981 standing crop after machine and hand harvesting May 1980 and April 1981.

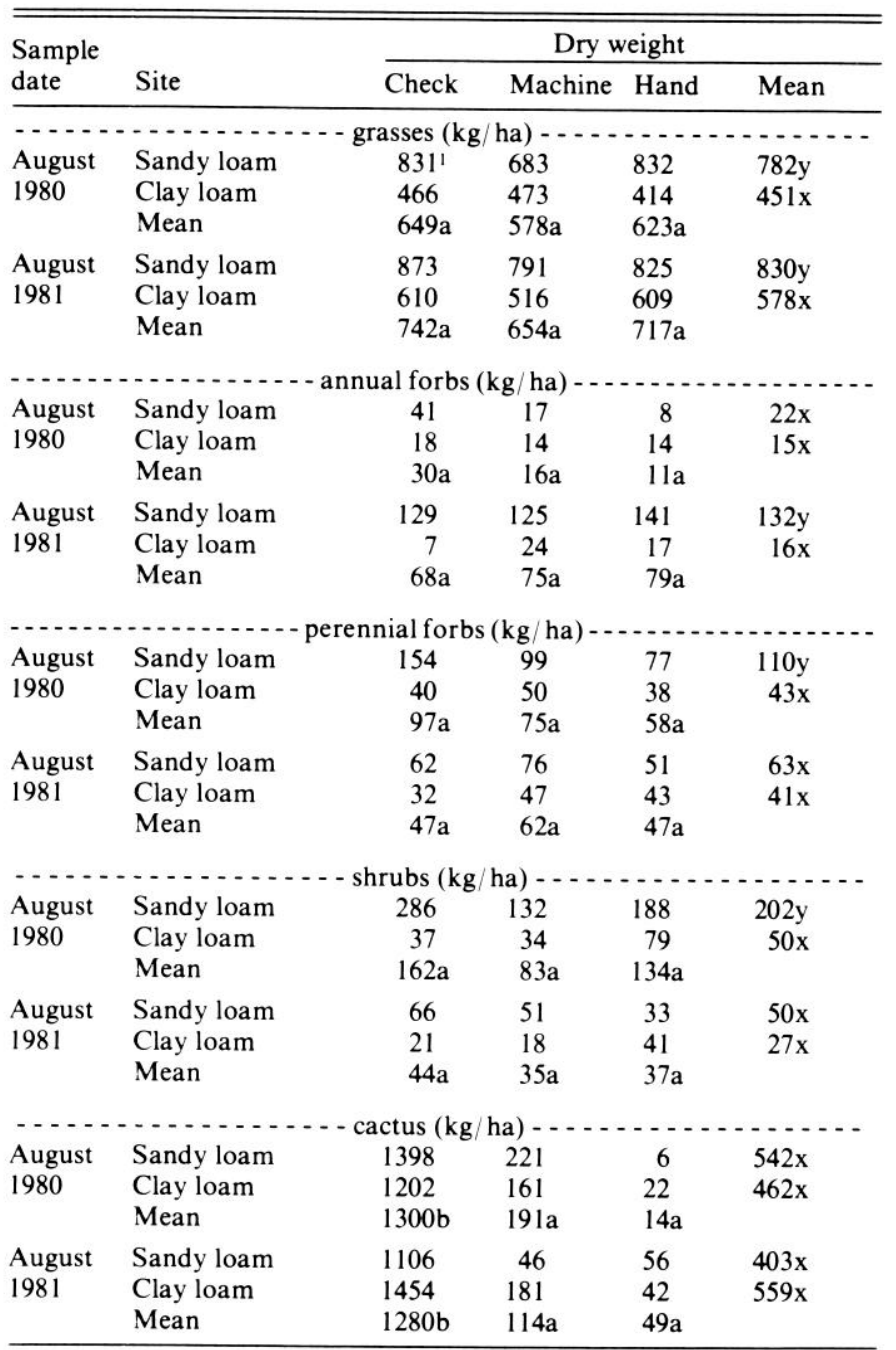

'Means within rows with the same letter are not significantly different $(P<0.05)$.

sub-plots for vegetation sampling. The machine-harvest treatment and control were replicated 4 times on each site. Hand-harvest treatment was replicated only twice because of the time required to uproot and remove pricklypear with hand rakes and forks.

Peak aboveground standing crop for all plant species was sampled in mid to late August of 1980, 1981, and 1982 using a weight-estimate method. Sampling was done on 25 quadrats $(30-X$ $30-\mathrm{cm}$ ) in each subplot. Field weights were converted to oven-dry weights based on samples of each species collected in the field and oven dried.

Analysis of variance was used to compare treatments. Duncan's new multiple range test was used for mean separation. Differences were considered significant at $P \leq 0.05$.

\section{Results and Discussion}

Control plot cactus production in 1980 averaged $1,398 \mathrm{~kg} /$ ha on the sandy loam site and $1,202 \mathrm{~kg} /$ ha on the clay loam site. In 1980 the pricklypear harvester removed all but $221 \mathrm{~kg} / \mathrm{ha}$ and $161 \mathrm{~kg} / \mathrm{ha}$ of pricklypear phytomass from the sandy and clay loam sites, respectively. In 1981, the harvester removed all but $46 \mathrm{~kg} /$ ha of the cactus from the sandy loam site and $181 \mathrm{~kg} / \mathrm{ha}$ of the cactus from the clay loam site. Cactus production on the sandy and clay loam 
Table 2. Cactus, forb, shrub, and grass standing crop in August 1982 of plots machine harvested and hand grubbed in May 1980 and April 1981.

\begin{tabular}{|c|c|c|c|c|c|}
\hline \multirow{2}{*}{$\begin{array}{l}\text { Harvest } \\
\text { date }\end{array}$} & \multirow[b]{2}{*}{ Site } & \multicolumn{4}{|c|}{ Dry weight } \\
\hline & & Control & Machine & Hand & Mean \\
\hline $\begin{array}{l}\text { August } \\
1980\end{array}$ & $\begin{array}{l}\text { Sandy loam } \\
\text { Clay loam } \\
\text { Mean }\end{array}$ & $\begin{array}{c}\text { rasses }(\mathrm{kg} \\
7891 \\
556 \\
673 \mathrm{a}\end{array}$ & $\begin{array}{l}\text { ha) } \ldots \ldots \\
695 \\
581 \\
638 \mathrm{a}\end{array}$ & $\begin{array}{l}687 \\
533 \\
610 a\end{array}$ & $\begin{array}{l}724 \mathrm{y} \\
557 \mathrm{x}\end{array}$ \\
\hline $\begin{array}{l}\text { August } \\
1981\end{array}$ & $\begin{array}{l}\text { Sandy loam } \\
\text { Clay loam } \\
\text { Mean }\end{array}$ & $\begin{array}{l}789 \\
556 \\
673 a\end{array}$ & $\begin{array}{l}778 \\
523 \\
651 a\end{array}$ & $\begin{array}{l}798 \\
547 \\
673 a\end{array}$ & $\begin{array}{l}788 y \\
542 x\end{array}$ \\
\hline $\begin{array}{l}\text { August } \\
1980\end{array}$ & $\begin{array}{l}\text { Sandy loam } \\
\text { Clay loam } \\
\text { Mean }\end{array}$ & $\begin{array}{l}\text { ual forbs } \\
46 \\
5 \\
26 a\end{array}$ & $\begin{array}{c}\mathrm{kg} / \mathrm{ha} \text { ) }-- \\
25 \\
4 \\
15 \mathrm{a}\end{array}$ & $\begin{array}{l}62 \\
14 \\
38 \mathrm{a}\end{array}$ & $\begin{array}{r}44 y \\
8 x\end{array}$ \\
\hline $\begin{array}{l}\text { August } \\
1981\end{array}$ & $\begin{array}{l}\text { Sandy loam } \\
\text { Clay loam } \\
\text { Mean }\end{array}$ & $\begin{array}{c}46 \\
5 \\
26 a\end{array}$ & $\begin{array}{c}39 \\
8 \\
24 a\end{array}$ & $\begin{array}{r}65 \\
5 \\
35 \mathrm{a}\end{array}$ & $\begin{array}{r}50 y \\
6 x\end{array}$ \\
\hline $\begin{array}{l}\text { August } \\
1980\end{array}$ & $\begin{array}{l}\text { Sandy loam } \\
\text { Clay loam } \\
\text { Mean }\end{array}$ & $\begin{array}{l}\text { Inial forbs } \\
\qquad \begin{array}{l}46 \\
33 \\
40 a\end{array}\end{array}$ & $\begin{array}{l}(\mathrm{kg} / \mathrm{ha})- \\
47 \\
29 \\
38 \mathrm{a}\end{array}$ & $\begin{array}{l}115 \\
38 \\
77 \mathrm{a}\end{array}$ & $\begin{array}{l}69 y \\
33 x\end{array}$ \\
\hline $\begin{array}{l}\text { August } \\
1981\end{array}$ & $\begin{array}{l}\text { Sandy loam } \\
\text { Clay loam } \\
\text { Mean }\end{array}$ & $\begin{array}{l}46 \\
33 \\
40 a\end{array}$ & $\begin{array}{l}78 \\
37 \\
58 a\end{array}$ & $\begin{array}{l}89 \\
31 \\
60 a\end{array}$ & $\begin{array}{l}71 y \\
34 x\end{array}$ \\
\hline $\begin{array}{l}\text { August } \\
1980\end{array}$ & $\begin{array}{l}\text { Sandy loam } \\
\text { Clay loam } \\
\text { Mean }\end{array}$ & $\begin{array}{c}\text { hrubs }(\mathrm{kg} \\
89 \\
39 \\
64 \mathrm{~b}\end{array}$ & $\begin{array}{c}\text { ha) } \ldots . . \\
26 \\
11 \\
19 a\end{array}$ & $\begin{array}{l}45 \\
40 \\
43 b\end{array}$ & $53 y$ \\
\hline $\begin{array}{l}\text { August } \\
1981\end{array}$ & $\begin{array}{l}\text { Sandy loam } \\
\text { Clay loam } \\
\text { Mean }\end{array}$ & $\begin{array}{l}89 \\
39 \\
64 a\end{array}$ & $\begin{array}{l}63 \\
27 \\
45 a\end{array}$ & $\begin{array}{l}70 \\
36 \\
53 \mathrm{a}\end{array}$ & $\begin{array}{l}74 y \\
34 x\end{array}$ \\
\hline $\begin{array}{l}\text { August } \\
1980\end{array}$ & $\begin{array}{l}\text { Sandy loam } \\
\text { Clay loam } \\
\text { Mean }\end{array}$ & $\begin{array}{l}\text { actus }(\mathrm{kg} / \\
1240 \\
1175 \\
1208 \mathrm{~b}\end{array}$ & $\begin{array}{l}231 \\
271 \\
251 \mathrm{a}\end{array}$ & $\begin{array}{c}4 \\
15 \\
10 \mathrm{a}\end{array}$ & $\begin{array}{l}49 x \\
487 x\end{array}$ \\
\hline $\begin{array}{l}\text { August } \\
1981\end{array}$ & $\begin{array}{l}\text { Sandy loam } \\
\text { Clay loam } \\
\text { Mean }\end{array}$ & $\begin{array}{l}1240 \\
1175 \\
1208 b\end{array}$ & $\begin{array}{l}103 \\
196 \\
150 \mathrm{a}\end{array}$ & $\begin{array}{l}52 \\
62 \\
57 a\end{array}$ & $\begin{array}{l}465 x \\
478 x\end{array}$ \\
\hline
\end{tabular}

'Means within rows with the same letter are not significantly different $(P<0.05)$.

control plots in 1981 averaged 1,106 and $1,454 \mathrm{~kg} /$ ha, respectively (Table 1). The harvester removed an averaged of $89 \%$ of the cactus while hand harvesting removed more than $95 \%$ of the cactus; however, the difference was not significant (Table 1).

During 1980, before the pickup device was developed, attempts were made to windrow cactus from 2 swaths with the harvester. Weight of 2 windrows bent rake teeth and permitted some cactus buried beneath the first windrow to remain rooted, leaving a row of attached cactus. Addition of the pickup and conveyor in 1981 permitted cactus to be deposited in bags as it was harvested. The harvester-pickup combination did not leave rows of rooted cactus, which increased cactus removal efficiency on the sandy loam site from $84 \%$ in 1980 to $96 \%$ in 1981 . Advantages of the pickup device were not evident in pricklypear phytomass data on the clay loam site although the rows of partially remaining pricklypear were not left in 1981 (Table 1). Vegetation sampling the years that treatments were applied (1980 and 1981) showed no significant harvester effects on grass, forb, or shrub production (Table 1). However, 1982 vegetation sampling of treatments applied in 1980 and 1981 showed a significant reduction in shrub phytomass on the 1980 machine harvested plots (Table 2). An explanation of why shrubs were affected by harvesting in 1980 is not available.

\section{Conclusions}

The pricklypear harvester is as effective at removing cactus as hand grubbing and does not damage desirable grasses and forbs. In 1981, the harvester-pickup combination removed $96 \%$ of the cactus from a sandy loam site and $88 \%$ of the cactus from a clay loam site. Machine harvesting reduced cactus phytomass an average of $91 \%$ and provided $1,166 \mathrm{~kg} /$ ha of cactus as potential feed. Harvesting cactus by machine should not only provide winter and/or emergency feed, but should also make previously unavailable grass forages available to livestock. The prototype harvester addressed only function, and not durability or safety. A commercial unit would require heavier duty components and need to pass required safety standards.

\section{Literature Cited}

Alley, H.P., and G.A. Lee. 1969. Chemical control of plains pricklypear in Wyoming. Wyoming Agr. Exp. Sta., Bull. 497.

Costello, D.F. 1941. Pricklypear control on shortgrass range in the Central Great Plains. USDA Leafl. 210.

Grifriths, D. 1906. Feeding prickly pear to stock in Texas. USDA Bur. Animal Ind. Bull. 91.

Grifiths, D. 1912. The prickly pear as a farm crop. USDA Bur. Plant Indus. Bull. 124.

Hyde, R.M., A.D. Hulett, H.P. Alley. 1965. Chemical and mechanical control of plains pricklypear in north-eastern Wyoming. Agr. Ext. Ser., Circ. 185

Laycock, W.A. 1982. Hail as an ecological factor in the increase of prickly pear cactus. p. 359-361. In: J.A. Smith and V.W. Hays (eds.) Proc. XIV Int. Grassland Congr. Westview Press, Boulder, Colo.

Shoop, M.C., E.J. Alford, and H.F. Mayland. 1977. Plains pricklypear is a good forage for cattle. J. Range Manage. 30:12-17.

Sims, P.L. 1973. Effect of herbicides on the control of pricklypear cactus in northeastern Colorado. Colorado Agr. Exp. Sta. Progress Rep. No. 73-72.

Smith, M.A., J.L. Dodd, and J.D. Rodgers. 1985. Prescribed burning on Wyoming rangeland. Wyoming Agr. Res. Serv., Bull. 810. p. 10-11.

Thatcher, A.P., G.V. Davis, H.P. Alley. 1964. Chemical control of plains pricklypear in southeastern Wyoming. J. Range Manage. 17:190-193.

Woodward, T.E., W.F. Turner, and D. Griffiths. 1915. Pricklypear as feed for dairy cows. J. Agr. Res. 4:405-450. 